\title{
The Effect of Organic Rice Productivity on Bali Food Security: A Case Study in Subak Peguyangan Denpasar, Bali
}

\author{
Kadek Wulandari Laksmi $\mathrm{P}^{1}$, Ni Wayan Lasmi ${ }^{1}$, Desak Made Sukarnasih ${ }^{1}$, I Gusti Ayu Wirati Adriati ${ }^{1}$ \\ ${ }^{1}$ Faculty of Economics and Business, Universitas Pendidikan Nasional, Bali, Indonesia \\ Correspondence: Kadek Wulandari Laksmi P, Faculty of Economics and Business, Universitas Pendidikan \\ Nasional, Bali, Indonesia.
}

Received: August 23, 2019

Accepted: October 1, 2019

Online Published: October 21, 2019

doi:10.5539/ibr.v12n11p22

URL: https://doi.org/10.5539/ibr.v12n11p22

\begin{abstract}
This aimed at analyzing the level of productivity of rice produced by organic rice farmers and non-organic rice farmers in Subak farmer group in Peguyangan Village, Denpasar. From these results, an efficient and effective alternative solution was further formulated by a farmer group to determine the decision on growing organic or non-organic rice. This research was prompted by the concepts of food security, theory of productivity and costs. The research used primary data sourced from subak farmer groups in Peguyangan Village, Denpasar and from documents that existed in the farmer group. The analysis results showed that the difference in the level of significance of organic rice was 0.740 while the non-organic rice had a significant level of 0.581 . This result means that the level of productivity produced for organic rice is greater than that of non-organic rice. Based on these results, it is recommended that subak farmer groups in Peguyangan Village, Denpasar plant organic rice because its significance level is greater than that of non-organic rice but also not have to completely ignore growing non-organic rice to stabilize the food needs of Balinese people.
\end{abstract}

Keywords: food security, productivity, organic rice, non-organic rice

\section{Introduction}

In Law Number 18 of 2012 concerning Food, it is stated that food arrangement aims to improve the ability to produce food independently, provide diverse foods and meet the requirements of security, quality and nutrition for public consumption, realize the level of food sufficiency, especially staple food at reasonable and affordable prices, in line with the community needs. In addition, it is to facilitate or increase food access for the community, especially the people vulnerable to food and nutrition, increase the added value and competitiveness of food commodities in the domestic and foreign markets, increase public knowledge and awareness about safe, quality and nutritious food for public consumption. Other important goals are to improve the welfare of farmers, fishermen, fish cultivators, and food entrepreneurs and protect and develop the wealth of national food resources. Rice is one indicator of food and is a basic necessity of Indonesians, including Balinese. Rice circulating in the community is classified into non-organic rice and organic rice. Organic-based agriculture is also one form of green revolution as a manifestation of improved planting systems and in order to maintain agricultural sustainability.

The development of organic rice in Bali is part of the organic farming that is being promoted. In line with the practice of organic farming in Indonesia, this practice has actually been applied by the Balinese people through the subak system, that is, organic farming practices that use the concept of harmony between God, humans and environment (Wiguna, et al, 2005 and Priadi, et al., 2007). Planting organic rice is still a problematic debate because, on one hand, planting organic rice has a positive impact on the environment and health and can maintain environmental sustainability. However, on the other hand, the limitations of organic rice cannot compensate for food needs amid increasing population growth rates (Priadi, et al., 2007). In addition, The Soil Association and Sustain (2000) describe that world food availability have been fulfilled. The incidence of hunger, in this case, is caused by poverty and income levels, not because of an imbalance in the food supply.

This condition becomes a dilemma in deciding on whether to plant organic or non-organic rice from the perspective of rice farmers' income. Organic rice produced by farmers in Bali is needed by the Indonesian people in general and the Balinese in particular. This condition is also one support of Balinese farmers in maintaining and increasing organic-based food commodities such as rice, vegetables, and yams. Planting organic rice also 
requires relatively inexpensive costs because it does not require a variety of other chemicals but the planting process takes longer which results in high selling prices. However, the information about the benefits and marketing of organic rice is still very minimal, so it has not reached a wider scope. Meanwhile, in other conditions, the need for organic rice has increased again, accompanied by an increase in people's understanding of the importance of consumption of organic food and maintaining health stability despite its high level of price.

The total population of Bali of 4,104,900 people while the need for rice is around $139 \mathrm{~kg} / \mathrm{year} / \mathrm{soul}$ and the total area of rice planting is 143.733 hectar, (BPS Bali, 2018). While organic rice planting is still very narrow, it is noted in Pegayungan Subak itself, the area planted with organic rice is 37 hectares with a total production of 230 tons and the amount of non-organic rice production is around 245 tons. The problems arise in fertilization where the production of organic rice for the first year needs maximum use of organic fertilizers, but the use of fertilizers at the next stage of harvest decreases, because the soil is getting fertile, whereas if using pesticide fertilizers is in contradiction; the more often the harvest is done, the more fertilizer is needed to use. Another problem occurs in rice prices where organic rice is higher in price than that of of non-organic rice.

Based on the description above, this study will analyze the level of comparison of productivity in planting organic and non-organic rice in Subak farmer group of Peguyangan, Denpasar, Bali, viewed from the community perspective on farmers' income. Furthermore, from the results of the analysis, alternatives will be identified in the preference of rice plants between planting organic and non-organic rice.

\section{Literature Review}

\subsection{History of Subak}

Water as a natural resource seems to have been managed well in Ancient Bali. Written in Tengkulak A 945 Saka/1023 AD inscriptions, the expressions amabati, amaluku, atanem, amatun, ahani, anutu were found, meaning "clearing land, plowing, planting, weeding, reaping, pounding ". Dawan 975 Saka Inscription has the term rotting banyu which means a kind of "water tax". Samgat Nayakan Air position was an officer who managed irrigation water stated in Bungli Pura Kehen B inscription, while ser danu was "the officer who managed the lake as a source of water for irrigation" as mentioned in the Trunyan AI inscription published in 833 Saka (Setiawan, 2003).

Philosophically, the word subak comes from the word "suwak" while the subak region in the past was called "kasuwakan". The word "kasuwakan" was written on the inscriptions: (1). Pandak Bandung made by King Anak Wungsu in 1071 AD, (2). Banjar Celepik-Tojan Klungkung made in Caka year 994 or 1072 AD, (3). Pengotan Bangli, which was made in Caka year 846, and (4). Bwahan Kintamani Bangli which was made in Caka year 916. In Pandak Bandung inscription, it was mentioned that the farmers in kesubakan Telaga at that time $\left(11^{\text {th }}\right.$ century), every third and ninth months began to get ready in working on the fields by first making three ponds ("tembuku") (Purwitha, 1986). Besides, it was explained how Subak was governed, some of which were by regulation of taxes that had be paid, determination of the boundaries of subak, the area of the subak area, including the establishment of rice fields to be used as "pelaba pura". One-third of the yields produced by rice field that was used as a "pelaba" was handed over to the King while the remaining two-thirds were handed over to subak officials to then be used to hold religious rituals in subak (Artha, 2016).

Subak in Bali is a fairly old irrigation cultural heritage (Pasandran, 1991). Based on the sources of inscriptions, it is informed that in the middle of the $11^{\text {th }}$ century the subak organization had been known in Bali. This is based on information in Pandak Bandung inscriptions of 993 Saka/1071 AD issued by King Anak Wungsu who mentioned kasuwakan talaga (Persubakan Talaga). Furthermore, Klungkung A, B, C inscriptions, marked 994 Saka/1072 AD mentioned rawas kasuwakan. Meanwhile, in Bugbug inscription marked 1103 Saka/1181 AD issued by King Jayapangus it was mentioned that kasuwakan bunglunan and prang (Subak area of Bunglunan and Prang) were practiced in Bugbug Village area. It was also mentioned in Pengotan Inscription C II (no year) that was allegedly issued by King Jayangpus. Thus, based on written data (inscriptions) it is stated that subak emerged during the reign of King Anak Wungsu, the youngest son of King Udayana Warmmadewa (Setiawan in Culture no 10/1995: 69).

According to R. Chambers (in Setiawan, 2003), the organization of irrigation water management emerges as a result of the physical system of irrigation. To ensure the smooth running of irrigation, an organization is needed, even though it is not formally formed in the general sense. Farmers usually do not willingly take the time to form a complex and complicated organization if the local ecology and area are not demanding such an organization. It is confirmed that the emergence of subak organizations in Bali is related to ecological factors due to severe ecological challenges. Farmers are required to work hard to get water; thus, the value of water becomes expensive and it demands accurate and equitable water distribution (Setiawan, 2003). The existence of Subak 
organization is also based on the geographical and ecological effects, according to the level of ease in access to obtaining water for farmers' irrigation.

Subak is also a tourist and cultural icon that has a strong existence in the Province of Baliso that its existence is recognized worldwide. In the past few years, UNESCO also recognized the existence of Subak in Bali as one of the world's cultural heritage sites. The uniqueness of Subak has a complex essence that contains various life values, including religious values, social values, and ecological (environmental) values.

\subsection{The Concept of Food Security}

Food security is a concept to harmonize the life and well-being of a community seen from the sufficiency of food and the accessibility of the resources for a long period of time and do not cause food problems for individuals or community groups. Food security is a primary component of survival because food is an energy source in carrying out activities. According to World Health Organization (WHO), three important components in food security consist of food availability, food access and food use to support sustainability. The concept of food security arises when a food crisis occurs marking the beginning of fluctuations in food supplies and prices resulting in food shortages (Napoli, 2011). This phenomenon finally leads to a variety of new policy frameworks to overcome the problems of food crisis through various studies of food security to maintain food stability and survival. In addition to the three components presented by WHO, Food and Agriculture Organization (FAO) also adds the fourth component related to food stability. Government regulations have a major contribution in influencing people's access to food.

\subsection{Concept of Attitude}

The attitudes of farmer groups in Peguyangan Village, Denpasar are: first, to have knowledge and perceptions about the climate or season that is suitable to start planting rice; second, some farmer groups in Peguyangan Village, Denpasar still plant non-organic rice and some others want to change to organic farming, in this case planting organic rice, but still think about the level of productivity or yields resulted from rice cultivation, whether organic yields are higher, or planting non-organic rice; third, for farmer groups in Peguyangan Village, Denpasar, that already know that the price of organic rice is much higher than that of non-organic rice, they have a high respect for the planting of rice. According to Tricomponent Attitude Model (Schiffman and Kanuk, 2010; Engel, et al., 1995), attitudes consist of three components: cognitive, affective and conative (psychomotor).

Cognitive is knowledge and consumer perception (obtained through experience with an object), attitude, and information from various sources. Knowledge and perception are usually in the form of belief, that is, consumers believe that the product has a number of attributes. This belief is usually formed naturally. Cognitive is also often referred to as consumer knowledge and trust. Meanwhile, affective is an expression of one's feelings and emotions towards a product or brand. Feelings and emotions are a comprehensive evaluation of the attitude toward an object (product or brand). Affective expresses consumer judgment on a product whether it is good or bad, liked or disliked. A person's feelings and emotions are primarily addressed toward the product as a whole, not described by expressing two different attitudes to evaluate a product. This component is formed by all things concerning emotions. Meanwhile, conative is the third component of the attitude that describes the tendency of someone to take certain actions related to the object of attitude (product or brand). Conative can also include behavior that actually occurs. Conative components in consumer research usually express the desire to buy from a consumer (intention to buy). This component is a component that will encourage people to take action. Therefore, after successfully forming perceptions in the two components above, it is still necessary to provide something that will encourage them to immediately make a purchase. Recommendations, discounts, guarantees are components that will form this component.

\subsection{Concept of Productivity}

Productivity is an output produced from the use of resources effectively and efficiently, but the quality of the products produced can compete in the community. The concept of productivity according to the 1984 OSLA charter (Ravianto, 1986) is a universal concept, intended to provide more and more goods and services for more people using fewer resources. Productivity is based on a multidisciplinary approach that effectively formulates the goals of development plan and the implementation of productive ways by using resources effectively and efficiently while maintaining quality. Integrated productivity integrates various production factors including capital, technology management, information and other resources that support the production process.

Hakim, (2014) point out that on the agronomic side the advancement of productivity is carried out through consistent and structured stages. For example, in managing organic rice planting, steps are taken using non-chemical materials from the stage of tillage to harvest. This is done to maintain the quality of organic rice 
products so that they are not polluted by ingredients that do not support their naturalness. Productivity as a ratio between inputs and costs to produce a maximum output (Martoyo, 2013). Thus, output from high-quality productivity requires balanced inputs and costs.

Based on philosophical concepts, productivity as a view of life and mental attitude to always try to improve the quality of future life. This gives the impetus to try and develop themselves to be better. Furthermore, the concept of system, provides guidance on the thought that the achievement of a goal must involve cooperation or integration of the relevant elements as a system with a similar purpose and mission (Simanjuntak, 1987). In this case, to increase productivity there must be good cooperation between workers and maintain a mental attitude in carrying out their duties and remain efficient using organizational resources.

\subsection{Concept of Costs}

According to Hansen and Mowen (2012), costs are one factor in productivity and as cash or value sacrificed to obtain an output of goods or services that can provide benefits. In this study, the costs involved include costs for the planting process starting from land processing to the final stage to harvest rice. In this study, the conceptual framework is outlined in Figure 2.1 as follows:

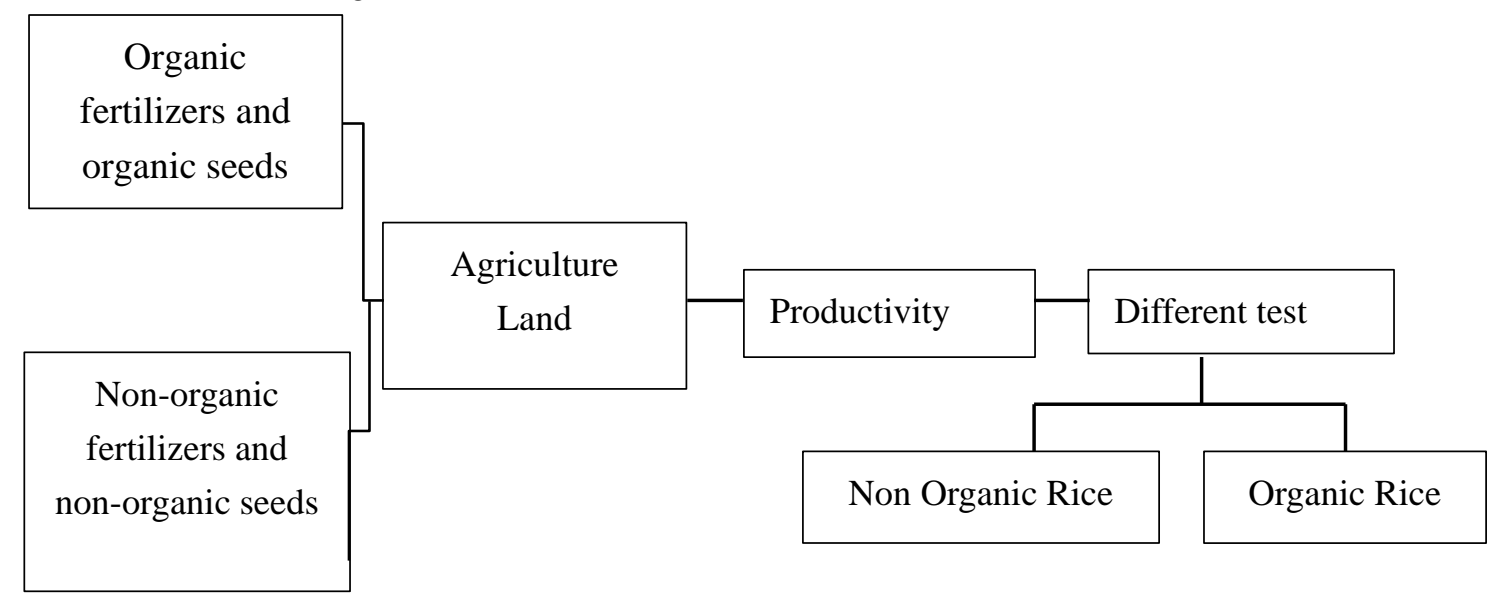

Figure 1. Optional Alternative Models for Planting Organic or Non-Organic Rice to Subak Farmer Groups in Peguyangan Denpasar

\section{Method}

This research was conducted in Subak Peguyangan, Denpasar, Bali Province. The location was chosen because Subak Farmers in Peguyangan Denpasar were facing problems in terms of rice planting, whether planting non-organic rice or planting organic rice in a community perspective on income. This research used descriptive method, to describing the condition of the situation in the field through indirect observation, recording through documents and interview with rice farmers in Subak Peguyangan, Denpasar to obtain the needed information. Through these activities, the required data. The next steps are identifying problems in the field, evaluating problems, analyzing them, and finally providing a solution (Nugroho, 2010). This research was carried out in Subak Peguyangan, Denpasar. The population in this study was rice farmers in Subak Peguyangan, Denpasar, in total of 200 farmers. The samples used were $20 \%$, so the number of samples was 40 people. If the subjects are more than 100, the samples to be used are between $10 \%-15 \%$ or $20 \%-25 \%$ (Arikunto, 2014). The data sources used in this study were primary and secondary, directly from farmers in Subak Peguyangan and from the documents that the farmers had. The data obtained were in the form of qualitative and quantitative. Data collection techniques used indirect observation, structured interview, and documentation. Data Analysis applied descriptive method with the steps as mentioned above with the formula used as follows:

$$
P=\frac{o}{I} \times 100 \%
$$

Notes:

$\mathrm{P}=$ Productivity of rice yields 
$\mathrm{O}=$ Output produced, in this study in the form of non-organic rice and organic rice.

I = Input used, in this study in the form of non-organic rice seeds and organic rice seeds, labor used, non-organic fertilizers and organic fertilizers.

The next step is to take a t-test, which is to find out the average difference. In this case, the differences in productivity produced between planting non-organic rice are compared to planting organic rice, in the community's perspective of incomw with hypotheses as follows:

Ho: The average productivity of non-organic rice produced by farmers in Subak Peguyangan Badung is not different from the average productivity of organic rice.

Ha: The average productivity of non-organic rice produced by farmers in Subak Peguyangan Badung is different from the average productivity of organic rice.

\section{Results}

\subsection{Data Description}

Data description is made to obtain conclusions in conducting research. The next step is processing the data to qualify the scores obtained. Processing data in a study is conducted to find answers to the formulation of the problem that has been proposed previously. Data analysis was performed using descriptive analysis and further analyzed by Statistical Product and Service Solution (SPSS) Series 17.

The generated data are about the productivity of organic and non-organic rice farmers in Subak Peguyangan. The results are figures obtained from two sample groups; organic rice farmers and non-organic rice farmers. The following is the results of the description of each group taken.

\section{a. Data Description of Organic and Non-Organic Rice Productivity}

In the data description of rice productivity in Subak Peguyangan, a general description of the research data is presented below. The data presented are the number of samples, average, standard deviation, variance.

Data in this table provide a rough description of the data produced in each group. Data are described by table presentation format.

Tabel 4.1. Data Decsription of Organic and Non-Organic Rice Yields

\begin{tabular}{lllll}
\hline Sample Group & N & Average & Satandard Deviation & Variance \\
\hline Organic Rice & 40 & 113.92 & 11.52 & 132.8 \\
Non-Organic Rice & 40 & 86.08 & 11.28 & 127.3 \\
\hline
\end{tabular}

Based on the data description of rice productivity of Subak Peguyangan farmers, it can be seen that in average the organic rice yields are higher than non-organic rice yields. It can be assumed that the productivity of organic rice is higher because the costs and yields and sales of rice are more effective.

\subsection{Normality Test}

The first step taken before testing the hypothesis is to take a normality test in order to obtain information about the data whether they are in normal distribution. In addition, data normality test will also determine the steps that must be taken next i.e. what statistical analysis should be used and whether using parametric or non-parametric statistics. The step taken is to input and analyze data using the "explore description" contained in "descriptive stasistics" on "analyze data" on the SPSS Series 17 menu.

The normality test of the output produced by SPSS 17 program has four data normality analysis tests, namely kolmogorov smirnov, Shapiro-wilk, Normal Q-Q Plots, and Detrended normal Q-Q Plots. The four analysis tests actually support each other. The normality test in this researchy refers to the analysis of Shapiro-Wilk, and $Q Q$ Plots with the assumption that samples within the same amount or more than 30 people are classified as the large sample group, then testing with Shapiro-Wilk is very relevant.

The following are the results of the normality test from the research data that has been obtained from each group of research samples in Table 4.3.

\section{a. Results of Data Normality Test of Organic and Non-Organic Rice Productivity}


Table 4.2. Results of Data Normality Test of Organic and Non Organic Rice Productivity

\begin{tabular}{llllll}
\hline \multirow{2}{*}{ GROUP } & \multicolumn{2}{l}{ Shapiro-Wilk } & \\
\cline { 3 - 6 } & & Statistic & Df & Sig. & Conclusion \\
\hline \multirow{3}{*}{ Organic Rice } & 0.981 & 40 & 0.740 & Normal \\
& Non-Organic Rice & 0.977 & 40 & 0.581 & Normal \\
\hline
\end{tabular}

- Lilliefors Significance Correction

- This is a lower bound of the true significance.

The analysis is based on probability values (Sig.) which are compared with the degree of freedom of $\alpha 0.05$. From the table above, the results of normality test using Shapiro-Wilk are as follows; organic rice productivity probability value (Sig.) is 0.740 , while non-organic rice productivity probability value distribution (Sig.) is 0.581.To test the results of these outputs, there are several provisions that become a benchmark. The following are some steps and provisions for normality tests from the data in Table 4.2.

Decision Criteria:

1) Sig or probability value $<0.05$ (Distribution is not normal),

2) Sig or probability value $>0.05$ (Normal Distribution)

Normality Test:

1) Organic Rice: Sig. 0.740> 0.05 (Normal Distribution).

2) Non-Organic Rice: Sig. 0.581>0.05 (Normal Distribution).

For the Difference in Difference

1) Results of planting of organic rice rice Sig $0.740>0.05$ (normal distribution)

2) Results of planting non-organic rice, Sig $0.581>0.05$ (normal distribution)

Thus, the probability value Sig for the difference in difference of planting of organic rice is Sig 0.740 greater than 0.05 as well as the difference in difference of planting of non-organic rice with Sig 0.581 greater than 0.05 . Referring to the provisions, if the probability value or significance is greater than 0.05 , then the data are in normal distribution. Based on the results of data analysis, it can be concluded that data on difference in difference of the yields of planting organic rice and planting non-organic rice are at normal distribution level. Whereas seen from the significance level of organic rice, the level is significantly higher compared to non-organic rice.

\section{Discussion}

From the analysis above and referring to the phenomenon, the comparison of the level of productivity produced by subak farmer groups of Peguyangan Denpasar, the average productivity of organic rice produced is greater than that of non-organic rice. For organic rice, the average productivity is 113.92 , while for non-organic rice the average productivity is 86.08 . Viewed from the average level of productivity produced by Subak farmers group of Peguyangan Denpasar, the farmer groups prefer to plant organic rice. This is also supported by the results of difference test, where the significance level of growing organic rice is greater or more significant than that of planting non-organic rice. The results of this study also support Law No. 18 of 2012 concerning food whose purpose is to improve the ability to produce food independently and to meet the requirements for quality and nutrition security for public consumption.

The production of food crops, especially rice, in each district experiences different movements during the period of 2000-2015. Figure 2 shows the different fluctuations in each district in the province of Bali for rice production. However, some districts also show an increase and decrease in rice yields. This condition was shown in Jembarana, Gianyar and Klungkung Regencies which tended to increase rice yields from 2014 to 2015. Meanwhile, in other Regencies such as Tabanan and Badung, they showed a significant decrease in rice yields. On the other hand, other regencies such as Bangli, Karangsem, Buleleng and Denpasar, a downward trend appeared even though it is not significant compared to Tabanan and Badung Regencies. One of the triggers for the decline in production land is indicated by the narrowing agricultural land and land conversion. This condition implies that rice fields must be maintained to maintain the supply of rice production, especially for organic rice which can provide great benefits to the community both in terms of food availability and export activities outside the region. 


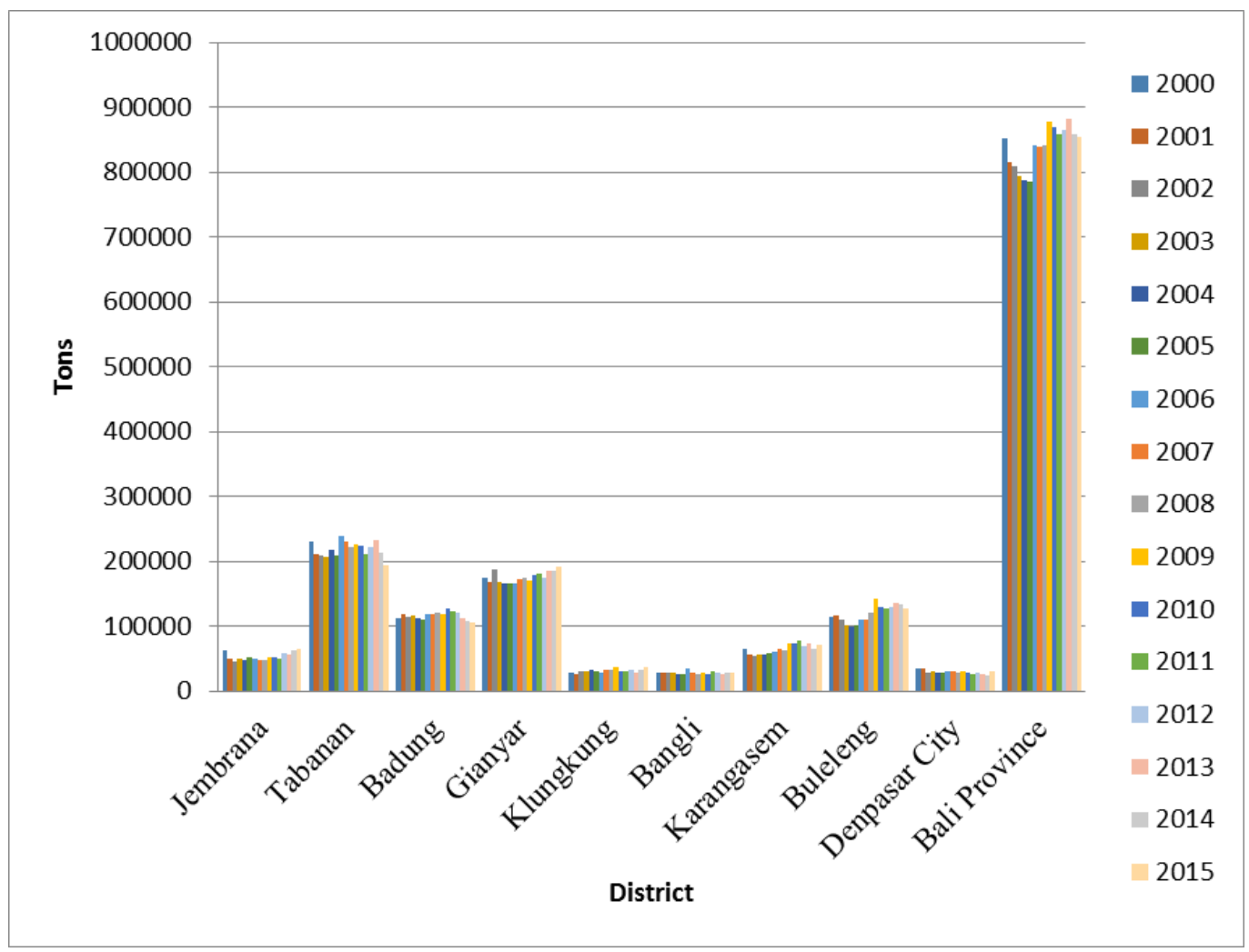

Figure 2. Development of Rice Production in Bali (2000-2015)

(Source: BPS Bali, 2019)

\section{Conclusion}

From the analysis and discussion above, some conclusions can be drawn:

a. Viewed from the comparison of the average productivity produced between organic rice and non-organic rice, the average organic rice is 113.92 , whereas the average of non-organic rice is 86.08 .

b. The level of productivity of planting organic rice is greater than that of planting non-organic rice. The alternative that can be chosen is to plant organic rice rice

c. This alternative truth can be seen from the significance level; the significance level of organic rice is 0.740 while significance level of non-organic rice is 0.581

Based on the results of the discussion and conclusions, it can be suggested that the level of productivity produced for organic rice is greater in yields than that of planting non-organic rice. Its significance has been tested. The significance level of yields of organic rice is more significant than that of non-organic rice. Thus, it is recommended that farmer groups better grow organic rice, but planting non-organic rice also needs attention in order that market needs can be met and the food stock is maintained.

\section{Acknowledgments}

This research was supported by Faculty of Economics and Business Universitas Pendidikan Nasional, Bali Indonesia.

\section{References}

Arikunto, S. (2014). Prosedur Penelitian. Jakarta: Rineka Cipta.

Artha, I. N. (2016). STRUKTUR ORGANISASI SISTEM SUBAK DI BALI. Program Studi Agroekoteknologi Fakultas Pertanian Universitas Udayana 2016.

Badan Pusat Statistik Provinsi Bali. (2019). Retrieved from www.bali.bps.go.id

Bali, D. A. (2018). Publikasi Bali dalam Angka.

Engel, J. F. et al. (1994). Perilaku Konsumen, Jilid 1. Jakarta: Binarupa Akasara.

Garvin, N. (2001). Manajemen Bisnis Total. Jakarta, Gramedia. 
Halim, A. (2010). Akuntansi Daerah Sektor Publik. Jakarta, Salemba Empat.

Hansen \& Mowen. (2012). Manajemen Biaya. Jakarta, Salemba Empat.

J. Ravianto (1986). Piagam Osla.

J. Simanjuntak, P. (1987). Pengukuran Produktivitas. Jakarta, Ghalia Indonesia.

Martoyo, S. (2013). Manajemen Sumber Daya Manusia. BPFE. Yogyakarta.

Mustofa, M. H. (2014). Perbandingan Tingkat Produktivitas Pendapatan Petani Padi Pengguna Pupuk Organik Pada Agroekosistem Lahan Yang Berbeda di Sumatra Selatan. In Proceeding of National Seminar on Suboptimal Land, ISBN, 979-529-9, Tanggal 26-27 September 2014, Palembang.

Napoli, M. (2011). Towards a Food Insecurity Multidimensional Index (FIMI). Thesis Master in Human Development and Food Security, University Degli Studi, Rome.

Nugroho, J. (2010). Metode Penelitian Ekonomi. Bandung, Sinar.

Priadi, D., Kuswara, T., \& Soetisna, U. (2007). Padi Organik Versus Non Organik: Studi Fisiologi Benih Padi (Oryza Sativa L.) Kultivar Lokal Rojolele. Jurnal Ilmu-Ilmu Pertanian Indonesia, 9(2), 130-138. https://doi.org/10.31186/jipi.9.2.130-138

Purwita, I. B. P. (1986). Kajian Sejarah Subak di Bali.

Schiffman, L. G., \& Lesli, L. K. (2000). Consumer Behavior. 7th Edition. Upper Saddle River. New Jersey: Prentice Hall Inc.

Setiawan, I. K. (2003). Sejarah dan dinamika organisasi subak di Bali - Kajian berdasarkan sumber-sumber prasasti. Surakarta FSSR UNS, 2003.

Soil Association, standard 6.312, Standards for Organic Food and Farming, Bristol, (2000).

Sulistyani \& Rosidah. (2003). Manajemen Sumber Daya Manusia. Yogyakarta, Graha Ilmu.

Undang-undang Nomor 18 Tahun 2012 tentang Pangan.

Wiguna, I. W. A. A., Lorenzen, R. P., \& Lorenzen, S. (2005). Past, Present and Future Perspectives of Balinese Rice Farming. Retrieved from http:/ /www.rspas.anu.edu.au/rmap/projects/docs/ Lorenzen_farming.pdf

\section{Copyrights}

Copyright for this article is retained by the author(s), with first publication rights granted to the journal.

This is an open-access article distributed under the terms and conditions of the Creative Commons Attribution license (http://creativecommons.org/licenses/by/4.0/). 